\title{
Libibliograplíral Dotírs.
}

Animal Locomotion. By J. BHLt PerTranew, M.D , F.R.S., Sc. (International Scientific Series.) New Fork: I). $\Lambda_{\text {plpleton }}$ \& Co. 1874. I'p. 260 .

Dr. J'ETTIakisw's friends cannot but be greatly annoyed that he has written this book. IIe enjoyed the reputation of an original and painstakingr investigator, who had done much to advanee science. Though his studies on the arrangement of the fibres of the heart and of other hollow muscular orrans are not absolutely conclusive, they have always been highly esteemed. How much, then, is the appearance of the present book to be regretted! 'Though claining to be popular, seientifie and instructive, it is obscure, illogical and full of errors. It is no reflection on the anthor's acquirements to say that he is out of his depth, for it is no reproach to an anatomist that lie is unable to errapple with the most difienlt physical problems, hut it is a serions reproneh that he should either have very erreatly overestimated his powers, or else, as we suspect is the ease, have thought that his treatment of the subject was good enough for his realers. $\Lambda$ s a specimen of logic, take the following passagre:-"'That artilicial flight is a possible thing is proved beyond a doubt, lst, by the fact that flight is a natural movement; and, 2l, because the natural movements of walking and swimming have been successfully imitated." We have no time to see how many fallacien we could extract from these two propositions; as an argument it is precisely on a par with that of the Yankee schoolboy in the poem of the "flying machine":-

"The biris can fly

And wliy cun't î ?"

$\Lambda$ s an example of style, take the following sentence:- "In the girafle, the legs of opyosite sides move together sund alternate, whereas in most quadrupeds the extremities move diacromally." Now; who that did not know that in the grirafle the legs of ench side move together and alternately with those of the other sidle, could learn it firom the above quotation?

Jesides an introduction and an appendix, the book consists of three parts, which treat respectively of locomotion on land, in the water and in the air. Though there is much to criticize, there is also a good deal to praise, and no one can reat the book withont profit. The figure-of-eight movement, which is becoming an "idle fixe" with the aththor, is shown to have a very ereneral application, though it is sometimes introduced in a prurely fantastic: mamer, as when it is drawn through the footprints of a guadruped. Dr. I'etiogrew speaks as follows of the relative importance of the osseous and muscular systems:- "The bony slieleton is a miracle of desien, very wonderful and very beatitill in its way. But when all has been said, the fact remains that the skeleton, when it exists, forms only an aljunct of locomotion and motion generally. All the really essential movements of an animal occur in its soft parts. The osseons system is, therefore, to be regarded as secondary in importance to the muscular, of which it may be considered a diflerentiation. Instead of regarding the muscles as alajed to the bones, the bones ought to be regarded as adapted to the museles." This is well expressed, and true as firr as it applices to those bones which are organs of locomolion, but an exeeption should be mate for such parts of the skeleton as are solely for the protection of enclosed organs. 'The aceonnt of the mechanism of the human walk is sketchy and inaceurate. The swintring lew ean be compared to a penduhm only with great restrietions. Meyer* has shown that the great mass of muscles eroing firom the pelvis to the thigh must interfere very seriously with a passive swing. 'Though l'ettigrew refers very frequently to the experiments of the Webers, he does allude to their discovery that to make the

- Statik und M echanik des Menschlichen Knockengerostes. 
log swing properly a certain impulse is necessary; now this is precisely what the foot, just as it leaves the erround, imparts to the led, so that the motion does not berin like that of a pendulum. Neither is it finished like one, for there is no donbt that in a step of ordinary lemerth the museles of the fiont of the thigh and lear come into play. But litfle weight is atlached to the horizontal rotation of the pelvis on the supporting femme, though this is a far more essential part of the step than the rotation of the leg and foot. We cannot understind how, "in walking, a spiral wave of motion, most marked in the antern-posterior direction (although also appearing laterally), ruus through the spine."

The chapter on progression on and in the water is very interesting, and, to our mind, the best in the book, thourh flying is more elnborately discussed. Dr. Pettigrew does not admit that the air-sacks of birds are for the purpose of assisting flight by reducing the weight, which he thinks is no part of the theory of flight, but a grave error, which has retarded our progress in ac̈ronautics. We shall not attempt to review this part of the book, which we may as well own we do not understand, though there is much in it of interest. 'To sum up as favorably as possible, if any one will wade through much that is obseure, fill out much that is crude, and overlook certain statements and reasoning which are evidently wrong, he cannot but gain in learning by the perusal, and were there a less distinguished name on the title. page he might not be very much disilppointed.

1. D. Jir.

Dictionary of Elcualions and Climatic Register of the Uniter Stales; Containing, in aldition to Elevations, the Latitude, mean 1 munul Temperature, and the total Annual Rain Fall of many Localilies; with a brief Intronluction on the Orographic amd other I'hysical Peculiarities of North America. By J. M. 'Tonen, M.1)., New York: D. Van Nostrand. 1874.

Tinlese are thirty-one pares entitled " Introduction," and nincty-three of the "Dictionary" form, in this pamphlet, and the anthor has inseribed his work with a well merited and neatly worded compliment to Prof. Joseph IIenry, JL.D., Secretary of the Smithsonian Institution.

1): 'Toner is already favorably known by his published writings, and the following paracraph, taken from a somewhat extended notice in the Irashinglon Star, seems to be well deserved testimony to his services:-

"The valious treatises by Dr. J. M. 'Toner, of this eity, upon matters of Social Science, have attracted attention, and have resulted in several instances in setting on foot very valuable reforms. One of the plans of an important sanitary and humanitarian natme broached by him has been that of establishing sanitariums on elevated grounds for the use of sick children in the hot season, a time of the year when the little ones are swept ofl by thousands by cholera infantum and like discases in our crowded citics. II trges with fores that our entire thought should not be expended upon the mere wrecks of humanity cared for in our hospitals, but should be directed also to the myriats of young lives now sacrified annually to disease, but who [which?] mient be saved to fill eareers of usefiuhess in the world."

The author has deriverl the materials for his work from the best sourcesamongst others, from "the Smithsonian records and contributions; from Chis. $\Lambda$. Schott's tables and results of precipitations; from Blodgeti's Cli-


sippi Valley; Forry's work on the Clinate of the United States, the $\Lambda$ rmy Meteorologrical Rerristem, the (ieologieal lieports of Prof. IFayden and others, various railroad surveys, United States Surveys and Expeditions, and from unpublished material in the possession of the departments of the Interior and $\Lambda$ griculture, the United States Signal Ollice," \&c. \&c.

In the "Dictionary of Elevations," the "lieight in feet above the sea level is given, of all the cities, towns and localities in the United states that the compiler has been able to find a measurement of." Wherever the clata could be obtained, the lititude and longitude, and also the mean annual temperaVOL. XC. No. 20A. 